\title{
US courts disagree on generic drug exclusivity
}

Confusion continues to reign over the rights to market generic drugs in the United States, despite a series of recent federal and district court cases. A provision of the US Drug Price Competition and Patent Term Restoration Act of 1984 (the Act) means that when a drug comes off patent-as many biotechnology compounds will in the next several yearsmanufacturers of generics cannot simply move straight into the market. Instead, the first generic drug maker-or "abbreviated new drug application (ANDA) applicant," in the regulatory jargon-to successfully challenge a pioneering patent enjoys 180 days of competition-free sales. This provision is intended as an incentive for generics companies to design around and challenge the validity of pioneering patents. However, two federal district courts that handed down conflicting rulings on generic exclusivity entitlement have not helped clarify what is actually required.

The first US federal court ruling, given in a case involving Mova Pharmaceutical (Caguas, Puerto Rico) and its generic diabetes drug, held that simply filing the ANDA first makes a company's product eligible for generic exclusivity. However, a second federal court, acting in a case brought by Novopharm USA (Schaumburg, IL), contradicted that saying that the filing alone is not enough; the first ANDA applicant must file, be sued by the pioneering drug maker, and then successfully defend the suit in order to be entitled to exclusivity.

Unable to comply with both court rulings, on November 28, 1997, the FDA struck up its own position, issuing a statement that generic exclusivity will be granted to the first ANDA applicant submitting a paragraph IV certification who is sued for patent infringement and successfully defends a suit.

Under a paragraph IV certification, an ANDA applicant asserts that the pioneering patent "is invalid or will not be infringed by the manufacture, use, or sale of the new drug. ..." That is the trigger for the patent owner to sue for patent infringement, in which case the ANDA cannot be approved for 30 months or until a court rules the patent is not infringed-whichever occurs first. A second paragraph IV ANDA from another company would not become effective for 180 days from the first commercial marketing of the first ANDA generic drug or a court decision holding the pioneering patent invalid or not infringed.

Ken Chahine is a patent attorney in Salt Lake City,UT (chahine@mmlaw.com).
What happens if a second company files an ANDA under paragraph IV, but the patent owner sues only the first applicant? This is the scenario that sparked the Mova litigation. In February 1995, Mova notified the Upjohn Company (Kalamazoo, MI) that it had filed an ANDA for its generic glyburide formulation, which it believed did not infringe Upjohn's glyburide formulation, Glynase, for treating type II diabetes. In March 1995, Upjohn sued Mova for patent infringement. Later in 1995, Mylan Laboratories (Pittsburgh, PA) filed an ANDA under paragraph IV for its generic glyburide, and notified Upjohn. Thinking the Act prohibited the US Food and Drug Administration (FDA; Rockville, MD) from approving Mylan's ANDA, Upjohn did not sue Mylan.

To Upjohn and Mova's surprise, the FDA granted Mylan's ANDA. Mova then filed suit to prevent the FDA from granting Mylan's ANDA or to change its effective date. Mova argued that the FDA's approval of Mylan's ANDA violated the Act because Mova was the first ANDA applicant. Under the act, therefore, the earliest effective date the FDA could grant Mylan's ANDA was 180 days from the date Mova commercially marketed its glyburide, or a federal court ruling on Upjohn's patent.

Although the FDA argued that without a successful-defense requirement the statute encourages frivolous ANDA filings for the sole purpose of delaying generic drug approval, the court sided with Mova, holding that nothing in the statute requires a "successful defense" by the first ANDA applicant. Mylan attempted to justify the successfuldefense requirement by arguing that even though the Act would permit Mova to market its generic glyburide after the 30 month stay expired (and begin the 180 day exclusivity), Mova would not risk selling its generic glyburide-Mova would fear losing the patent infringement suit with Upjohn and be liable for damages. Mylan and the rest of the generic glyburide market, therefore, would be hostage to Mova's decision to market glyburide and its lawsuit with Upjohn. But the court dismissed the arguments as speculation, and added that the FDA and Mylan's remedy "lies with Congress, not this Court."

Following the Mova decision, in June 1997, Genpharm (Canada) filed a paragraph IV ANDA for the generic version of GlaxoWellcome's (London) Zantac. In accordance with the Mova decision, the FDA did not approve subsequent ANDAs for generic Zantac despite the fact that Genpharm had not successfully defended its suit against Glaxo. The FDA's ruling was again challenged, this time by Novopharm USA, which filed the second ANDA. This time a US District Court ordered the FDA to follow its original interpretation of the Act, which requires a successful defense by the first ANDA applicant. Under the ruling, Genpharm could not market its generic Zantac because it was still litigating with Glaxo (or if it did risk patent infringement); Novopharm-despite its court victory over Glaxo-could market its generic Zantac, but presumably would have to halt sales for 180 days if Genpharm ultimately successfully defended its lawsuit with Glaxo and triggered the generic exclusivity period. "It is very complicated... we have never run into that situation - and we hope we never do," says Jerry Phillips of the FDA. To resolve further confusion, Novopharm acquired Genpharm's generic exclusivity period in a private settlement.

Last December, a jury in Puerto Rico decided that Mova's generic glyburide does not infringe Upjohn's Glynase patent, and that Upjohn's patent is invalid and unenforceable. Mova plans to market its generic glyburide immediately. Upjohn has appealed the ruling.

Ken Chahine

\section{EPA ban on bromoxynil undercuts Calgene's transgenic cotton}

Officials at the US Environmental Protection Agency (EPA; Washington, DC) announced late in 1997 that the registration for the herbicide bromoxynil would not be extended, and thus it may not be used for treating transgenic cotton plants during the 1998 growing season. The decision affects not only bromoxynil manufacturer Rhône-Poulenc
(Lyon, France) but also Monsanto (St. Louis, MO), which owns Calgene (Davis, CA) and its Stoneville (Memphis, TN) subsidiary, the producer and distributor of bromoxynil-tolcrant transgenic cotton seeds.

The EPA decision was made under authority of the Food Quality Protection Act, which sets stringent standards for pesti- 